\title{
$-\mathrm{x}=\mathrm{x}$ \\ African Research Review
}

AN INTERNATIONAL MULTI-DISCIPLINARY JOURNAL, ETHIOPIA

AFRREV VOL. 11 (2), SERIAL NO. 46, APRIL, 2017: 83-98

ISSN 1994-9057 (Print) ISSN 2070-0083 (Online)

DOI : http://dx.doi.org/10.4314/afrrev.v11i2.7

\section{Ikwerre Intergroup Relations and its Impact on Their Culture}

\author{
Chinda, C. Izeoma \\ Department of Foundation Studies \\ Port Harcourt Polytechnic, Rumuola \\ Phone No: +234 7036674797 \\ E-mail: Chiizeoma@yahoo.com
}

\begin{abstract}
This paper examined the intergroup relations between the Ikwerre of the Niger Delta, South-South geopolitical zone of Nigeria and its impact on their culture. It analyzed the Ikwerre relations with her Kalabari and Okrika coastal neighbours, as well as the Etche, Eleme, Ekpeye, Ogba Abua and the Igbo of Imo state hinterland neighbours. The paper concluded that the internal developments which were stimulated by their contacts impacted significantly on their culture.
\end{abstract}

Key words: Ikwerre, Intergroup Relations, Developments, Culture, Neighbour.

\section{Introduction}

Geographical factors aided the movement of people from one ecological zone to another in migration or interdependent relationships of trade exchange. These exchanges and contacts occurred even in pre-colonial times. The historical roots of inter-group relations of the Ikwerre with her neighbours, dates back to pre-colonial times but became prevalent from the 1850 onward when the Atlantic trade became emphatic on agrarian products as raw materials to the industrial western world. This galvanized the hitherto existing inter-group contact between the Ikwerre and her neighbouring potentates.

Copyright (C) International Association of African Researchers and Reviewers, 2006-2017:

www.afrrevjo.net.

Indexed African Journals Online: www.ajol.info 
According to Afigbo (1980, p. 122) "the links which bind the peoples are as ancient, deep and varied; and therefore, as important as the links internal to each state". Okpeh (2006), observed that man by nature is a dependent creature; he depends on his environment and others for food, shelter and clothing, all of which gives him a sense of purpose here on earth. As such, the fundamental need of man is the provision of material goods, which itself compels (by implication) co-operation with others in production/consumption relationship, involving competition for access to scarce resources (Otite in Okpeh, 2006). Even in the all-important question of the struggle for the basic things of life, human beings co-operate not just for the sake of social community, but indeed out of necessity. Similarly, Alagoa (1989), avered that the Niger Delta communities were never self-sufficient. They depended on the specialized fishing of their menfolk and on the exchange of their smoke-dried fish and salt with the people of the hinterland for bulk foodstuff, tools, clothing and domestic gears. Consequently, no human group, its level of development notwithstanding, can be said to be an island. This makes contact, interaction and interdependence not just a fact of life, but one which is universally constant and basic. Okpeh (2006) quoted Afigbo thus:

Intergroup relations presuppose contact and interaction between groups each of which has an identity, to make some inputs into the relationship, in short, each of which has some scope and area of autonomous action (p. 12).

What follows is the fundamental element of inter group relations, that is, the interaction which is the reaction of societies or groups towards one another. This ranges in various forms; philosophy, religion, legal and judicial system, political, economic, military and social, also, these relations could be positive or negative when they live in relative harmony and benefit from each other and negative when they are exposed to rivalry and unhealthy competition, this resulting in tensions, bitterness and hostilities. Though, sometimes, these relationships took the form of war and enslavement, they also expressed themselves through diplomacy, treaties, the borrowing of techniques and above all trade. Thus, regardless of the fact that each ethnic group has its unique identity, and occupies a contiguous territory, there was and has always been considerable contact between groups which antedate contact with Europe (Okpeh, 2006). In fact, the economic and political survival of an ethnic group depends on the relationship whether friendly or hostile, which it had with its neighbours. Also, commerce and social contacts led to linguistic borrowings and often to bilingualism among traders. Although trade links formed the basis of Ikwerre relations with their coastal neighbours, cultural dividends also followed.

\section{The Ikwerre and Her Neighbours}

The Ahia Oshimini, - markets along the Sombreiro River and New Calabar Rivers were avenues for exchange of goods between the coastal states of Kalabari, Okrika, Bonny

Copyright $($ I International Association of African Researchers and Reviewers, 2006-2017: www. afrrevjo.net.

Indexed African Journals Online: www.ajol.info 
and hinterland Ikwerre. The rivers were very important as they served as carriers of trade and culture. Ahia Izor/Apah (road market) served the Ikwerre and her Ekpeye, Ogba, Eleme, Etche, Abua, Igbo, hinterland neighbours. This market is said to be the earliest form of trading that existed in Ikwerreland. These markets (Ahia Oshimini and Ahia Uzo) not only provided avenues for exchange of goods but were also a major source for slave trade showing that before the arrival of the colonial masters, the Ikwerre people had contacts with her neighours through long and short distant trade (Emejuru, 2014).

As one of the major ethnic groups in Rivers State, Ikwerreland enjoys its strategic location between the coastal states of the Niger Delta and its hinterland neighbours. This was also based on the fact that the Ikwerre people were not belligerent. Ikwerre communities have not had any major conflicts with her neighbours, rather, they have developed cordial and fruitful relationship over the years. Also, the ecological differences between the Ikwerre and their neighbours made inter-group relation inevitable. Endowed with abundant arable land the Ikwerre produces much more than they needed in tubers and vegetables in exchange for fish, salt, farming equipment and other items they needed. This naturally led to the development of trade in exchange between them (Emejuru, 2014).

Contacts between the Ikwerre and her coastal neighbours had been peaceful and mutually beneficial. The Ikwerre who are mainly farmers and practices small scale fishing, exchanges their farm produce of cassava, yams, cocoyam, vegetable among others for fish brought by their costal neighbours who are fishermen. To keep good social and commercial relationships, they established reliable contacts and friendship with hinterland families. This manifested in the special relationship that was established between their coastal fishermen and particular hinterland communities. The people of Kalabari, for example were identified with the Ikwerre communities of Iwofe, Choba, Isiokpo, Ibaa, Ogbakiri, Emohua and Ndele, and the Okrika had intimate social links with the Ikwerre communities of Rumuokwurisi and Diobu. These contacts were strengthened through marriage and concubinage.

Ahia Apah (road markets) are in circles of four and eight days. The circles were such that interference was rare. They developed good relationship based on trade. The early contacts of Ikwerre and her neighbours predate Trans-Atlantic trade in slaves and in palm oil and palm kernel. Farm products moved in and out between the Ikwerre and their neigbhours. In the pre-colonial time, exchange was by barter and from Ikwerre communities, products such as; yams, cassava, cocoyam, palm oil and items like livestock and fisheries, including goats, fowls were exchanged for knives, cutlasses, hoes and diggers manufactured by the Awka smiths of Igbo. Apart from trade, the Ikwerre and their hinterland neighbours also promoted cultural relations.

\section{Ikwerre-Kalabari Relations}

Copyright () International Association of African Researchers and Reviewers, 2006-2017: www.afrrevjo.net.

Indexed African Journals Online: www.ajol.info 
Traditions from both the Ikwerre and Kalabari make reference to early Kalabari settlement in Ikwerre community at Obu Amafa. However, disagreement between the two groups led to the Kalabari dispersal to their new settlement. But the Kalabari continued in trade with the Ikwerre from their new settlement with fish and other sea foods being exchanged for farm produce. The Kalabari also depended on the Ikwerre forest produce for their boat building and other crafts (Alagoa, 1972). This relationship Bob-Manuel (2004) noted had spanned to present time. Also, Thom-Manuel Victor John (1999) maintained that the Ibaa and Ndele people of Ikwerre traded with the Kalabari at the Owusara in Abonnema. He further stated that Ndele traders were noted for their good yam and garri commonly called Ndele buru and Ndele garri respectively. The Kalabari also visited Ahai Ekhe in Ibaa to sell periwinkle and smoked fish. In exchange, they bought garri, yams, plantain, cocoa-yam and banana. In fact, the Mgbom traders (as they are usually called) stayed several days in their dug-out canoes in Ibaa (Chief Andy Somba, 20/2/2014).

Ikwerreland played host as producers and routes through which palm oil trade passed to the delta ports. The slave trade era was no exceptions as some parts of Ikwerre became collecting centres of slaves from the hinterland to the coast. Talbot (1967, p. 6), noted that the "principal slave marts were Isiokpo and Aloa (Aluu) on the Upper New Calabar River and Ndele on the Sombreiro River" (all Ikwerre communities). With the Second World War Abonnema (a coastal community) became an important part for palm produce. Some Ikwerre traders transported large quantities of palm produce for sale at Abonnema where the UAC Group of Companies where the principal exporters (Wobasi, 1976).

For purposes of convenience, some Kalabari neighbours chose to settle at certain Ikwerre water front strategic to their businesses. Owing to this, along the New Calabar/Obiatubo River, sprang such settlement in Rumuolumeni (Iwofe), Isiodu, Elibrada, Oduoha, Ewveku, Rumuji, Ibaa, Iku-kiri and Adala. There were also temporary market camps at Ogbogoro, Choba, Nkarahia (Isiokpo). On the Sombreirio axis, there were the market centres and temporary sites which facilitated economic as well as socio-cultural interaction among the Kalabari at Elele-Alimini, Rumuekpe, Rumuji, Itu and Ubimini. The fishing grounds of the Ikwerre (Ogbakiri) are Ikwukiri, Eghelu, Ahia-rire, Onuodogo, Nkpusi-ekwungwu, where Kalabari fishermen also fished. The Ikwerre also fished in Kalabari area of Minjidukiri, Opukiri, Dagbara, Elem-Tombia, Owukiri and Idama. In the course of fishing activities, fishing methods were exchanged. Similarly, some of the fish names were derived from the Kalabari language such as Atabala, Ikili, and sakam (Chukwu, 20/3/2014, Gbule, 18/8/2012).

This relationship was also strengthened by individual friendship. For instance, King Nnyevunwo of Ogbakiri on invitation of King Abbi Amakiri (Kalabari) paid a royal visit to the Kalabari state in 1871 . He was warmly received. Among other gifts, was an

Copyright (C) International Association of African Researchers and Reviewers, 2006-2017: www.afrrevjo.net.

Indexed African Journals Online: www.ajol.info 
ivory staff which served as a symbol of friendship and economic co-operation. This visit was to seal the friendship between the two states. Not only did the ivory staff formalize the diplomatic relation, it also showed the high regard the Kalabari state had for Chief Nnyevunwo (Nimi Wariboko, 2007, pp. 361-399; A. P. Okpara, 1980, pp. 59-70). Also, Chief Uchendu Osi of Emohua showed some piece of land at the Alakikia waterside to Kaiser Tom West, Omokwe family - Obene Obu and Olu Horsefall for purposes of trade. These Kalabari families gave imported materials like wines, guns, tinned fish, real India cloth to Chief Uchendu Osi. Other portions of land given to the kalabari by Emohua for the same purpose were Ahia Okereke, Onumini Ikiriko (Alumini Oduoha), Onumini Tariah-Ogbodo (Wobasi, 1976).

\section{Ikwerre - Okrika Relations}

The Rebisi and the Evo of Ikwerre have had long-standing relations with Okrika. The people of Okrika controlled the European trade which passed through the south-eastern part of Ikwerreland to other hinterland markets called Obiatubo located in Isiokpo and Akpor communities (Alagoa \& Fombo, 2001). The creek leading to Rebisi- Diobu provided access to the Ikwerre markets of Mgbuoshimini, Ahia Elechi and others for the Okrika and Kalabari traders. There are settlements of Okrika people on Ikwerre communities of Oginigba, Woji, Elelenwo and Rebisi-Diobu.

However, the establishment of Port Harcourt in 1913 and the economic imperatives of the strategic position of the city (Igwuocha) necessitated the claim of co-ownership of Port Harcourt (Igwuocha) by their trading partners-Okrika. With the exception of Rebisi-Diobu, the Okrika have left other Ikwerre communities where they had settled. The portion of land given to the Okrika by Ikwerre people of Rebisi/Diobu, is evidenced in the Suit No: P/107/67: Chief Timothy Agbaka and Anor for the Obanga family of Ogoloma vs Edward Amadi and others of Amadi family of Ogoloma: an action by two Ogoloma families living in Amadi village. Chief Agbaka, on his own admission, gave evidence that, sometime in 1893, his family was granted the land they lived on by late Chief Osa of Diobu. Nwanodi (1994) further avers that, as testimony for these grants, the case of Woluchem vs. Gudi (1980)5 SC is recalled. The High Court judgment in that suit which was an action for title to the lands east of Weja River against the Chiefs of Abuloma by Diobu Chiefs is "very instructive'; that the Government thus made it clear that they had abandoned all claims to the land to the East of Weja River (creek), i.e all lands between the Waja Creek and Woji River. This is the area now known as Trans Amadi industrial Estate and the area where Okrika Villages of Amadi Okuru Fimie, Abuloma and others were located by courtesy and grant of Diobu people. This village was shown on the map attached to the 1913 Agreement as Okrika Land and Villages. The Diobus have established their title to these lands in Suit No. P/46/66: Simon Gudi \& Ors of Abuloma, Okrika vs.Chief Victor Woluchem and others of Diobu.

Copyright (C) International Association of African Researchers and Reviewers, 2006-2017: www.afrrevjo.net.

Indexed African Journals Online: www.ajol.info 
The concluding portion of the judgment by Mr. Justice Alagoa of the case of Woluchem vs. Gudi (1980)5 SC, where Okrika people are now claiming joint ownership of Port Harcourt with Diobu people reads thus:

On the issue of trespass, it is not denied that the Defendants (Sic Abuloma people) have cleared an area for palm estate. It is shown on their plan as covering 26 acres of land. In view of my finding it was a clear act of trespass for the Defendants to have done so without any reference to the Plaintiffs. They must consider themselves lucky in view of the nature of their defence that the Plaintiffs (sic Diobu Chiefs) have not asked for forfeiture of the area they now occupy. . . (Nwanodi, 1994).

Nwanodi (1994), noted that, as a general rule, forfeiture is an appropriate remedy where customary tenants, such as the Abulomas, deny the title of their customary landlord, the Diobus. This suit was appealed and won by the Okrika people but finally won by the Ikwerre people at the Supreme Court. Yet, there has been media war between the Ikwerre- Diobu and Okrika people over the status of Port Harcourt with regards, to the real owners, but both communities have continued to exist relatively peacefully.

\section{Ikwerre- Etche Relations}

The relation between Ikwerre and Etche is also traceable to their traditions of origin. According to Amadi (1993), a version of the origin of Ikwerre people of Obio group among the southern Ikwerre, traced their links with Ozuzu in Etche to the north east where his $(\mathrm{Ozuzu})$ son, Ikwerre, moved to Elele from which the founders of the seven groups of Ikwerre communities spread to their present locations. This tradition is not popular among other Ikwerre people. In Etche the two main traditions of origin namely the Benin and Igbo versions make reference to Ikwerre. Amadi, (1993) and Ikechi Nwogu et al (2003) noted that the age-long umbilical cord relationship between the Ikwerre and Etche symbolized by the Ogba-Ige festival (a rite denoting brotherhood) to which the Ozuzu people invited the Ikwerre people to in pre-colonial times features in both Ikwerre and Etche nations.

The importance of this relation also lies in the fact of the proximity of the Etche and Ikwerre, the similarities between their socio-political and economic organization as well as their links in the Amadi-ohna Ozuzu in Etche and Ojukwu Diobu in Ikwerre. This according Amadi (2003) fostered their relations.

Between the Etche and Ikwerre, there exist trade transactions and markets, such as Ahia Ordunwe-Etche in Igwuruta, Ahia Igwocha of Port Harcourt and Ahia Inim of Elelenwo. Ahia Nwonti in Umuechem, Ahia Ozuzu in Ozuzu, Ahia Eke in Egwi and Ahia Eketa in Igbodo. There are also Ahia Aluu and Ahia Rukpokwu.

Copyright (C) International Association of African Researchers and Reviewers, 2006-2017: www.afrrevjo.net.

Indexed African Journals Online: www.ajol.info 
Besides trade, socio-cultural and recreational ties encourage good relationship between the Ikwerre and Etche people. For instance, the Otnuanya festival (rite of passage into manhood) is celebrated among the Ikwerre communities of Ozuaha, Omademe, Ipo and Etche.

In an oral interview, Hilary Wordu (15/4/2013), contended that owing to the closeness of the Ipo to Etche, the Ipo join Etche in the celebration of Amadi-Ohna festival. During the egwu Amadi Ohna festival, no manner of farm work is carried out in Ipo. The Etche people determine the day for the celebration. In his view, the egwu Amadi Ohna Ozuzu celebration was a form of marginalization which he described as "economic colonization". The assertion of Hilary Wordu meant that Ipo people depended on the whims and caprices of the Etche people for economic future during the celebration. However, with modernity and social change, the community is insisting that egwu Amadi-ohna should be discontinued. The Amadioha deity also served as an oracle which Ikwerre people consulted to seek redress. Some Ikwerre people eventually became worshippers of the deity. Amadi ohna is a prominent deity in eastern Nigeria.

An informant, Blessing Amaewhule (19/7/2010), noted that, during farming season, the Etche and Ikwerre, especially Igwuruta, engaged in cooperative farming. This process involves a large number of young men who must have been bounded together by age or common interest. This, to a very great extent, eases the labour challenges during farming.

The Ikwerre and Etche were also in same County Council and Local Government Area before the creation of Etche Local Government Area. The two groups donated land for the building of one of the foremost secondary schools in the area- County Grammar School Ikwerre- Etche. This enhanced the education of students from the area.

\section{Ikwerre - Eleme Relations}

The Elelenwo and Eleme had trading relation. Both are farming communities. The Eleme traded with Elelenwo at Odulukwu market. They also traded with the DiobuRebisi at the Ahia Elechi and Ahia Makara. The Eleme brought sugar cane, palm wine, firewood and bought clay pots for the storage of their palm wine and water. Eleme and Elelenwo also share farm boundaries and there have been no conflict between them. With the advent of Western civilization, Elelenwo community became a gateway to the capital city - Port Harcourt for the Eleme. The relationship was further enhanced with the introduction of Christianity and the establishment of schools in Elelenwo, which Eleme people attended.

\section{Ikwerre - Ogba, Ekpeye and Abua Relations}

Copyright (C) International Association of African Researchers and Reviewers, 2006-2017: www.afrevjo.net.

Indexed African Journals Online: www.ajol.info 
The Ikwerre have traditions which link them with the Ogba and Ekpeye origin, claiming to have migrated from Benin Empire. The Benin tradition continues to gain prominence among Ikwerre scholars. Nduka (1993) and Woka (1993, pp. 1-10) refer to the ancestors of the northern and central Ikwerre communities; Ochichi, Ekenta or Wezina (for the people of Ogbakiri) as relatives of one Akalaka who migrated from Benin and founded the Ogba and Ekpeye. Similarly, the oral tradition of the Ibaa, Obelle, Ogbodo, Omagwa, Ndele, Rumuji, Ogbakiri, Aluu in the northern and central sections of Ikwerrre talks about Akalaka and their migration from the north-west through Ekpeye land. Among the northern Ikwerre, their oral tradition as descendants of Ochichi stands strong.

Alagoa \& Kiebel (1989) mentioned Ekenta as the founding ancestor of the Ogbakiri through Ogba. The works of three non-Ikwerre scholars (Olise, 1997; Otuwa Rikpo, 1994 \& Solomon 2004) are quite instructive. They agreed that the origin of Ekpeye is linked with Ogba and Ikwerre, which traced their origin to Akalaka. Ubima and Omodioga have close links with the Ekpeye in their settlement history.

There is also the claim of origin from Abua among the Emohua, who asserted that their progenitor, Udele, migrated from Abua to Ndele from where they spread to their present settlement.

There are cultural ties that bind the Ekpeye communities and the Odegu-Ikwerre groups, especially Rumuekpe. Mention is made of periodic wars between the Ikwerre and Ekpeye, which were as a result of tensions concerning border conflict and population movement.

Wrestling and marriages were also features that further promoted their relations. The Owuama and Egbukele were masquerade displays from contact with the Abua. As earlier mentioned, these contacts were not devoid of linguistic affiliation, bilingualism and other cultural dividends.

\section{Ikwerre - Igbo Relations}

Ikwerre relations with the Igbo predate the Trans-Atlantic slave trade and trade in palm oil and palm kernel. Contact with Europe influenced the already existing trade relations. The most dominant Igbo traders were the Aro. The Aro developed regular routes of trade covered by organized troupes. The leaders of these troupes established elaborate networks of trading friends, allies and kinsmen. They also established a network of permanent settlements in Ikwerreland which enhanced their trading activity. They were able to achieve this because they were held in awe as a result of their association with the Aro oracle, Ibinukpabi. Apart from trade, most Aro settlers in Ikwerre came as emissaries of the long juju of Aro, Ibinukpabi.

Agumagu (1988), categorized the migration of Aro into Ikwerre in two phases: the early and later phases: the first phase covering the slave trade era up to the

Copyright $\odot$ International Association of African Researchers and Reviewers, 2006-2017:

$$
\text { www.afrevjo.net. }
$$

Indexed African Journals Online: www.ajol.info 
establishment of British administration 1700-1900, and the second phase covering the period of Nigeria independence and the end of Aro Oligarchy, 1901-1960. According to her, the early Aro came through Ozuzu in Etche to settle in Igwuruta, Omagwa, Isiokpo, Elele, Rumuekpe, Ubima, and Aluu.

During the colonial period, the Aro were appointed to occupy responsible positions. Nwocha Amefula and Osundu Oyo, both Aros in Isiokpo, were appointed Warrant Chiefs in Isiokpo to represent Omagwa, Ozuaha, Omademe and Ipo at Choba for seven years. Amakiri Nwocha, a member of Customary Court of Appeal in Omagwa, Nwosu Okorie Ebika, (village Counsellor) a tax agent and a rate collector. They generally participated in the local government and customary court administration. In Omudioga, Aluu and Omagwa, the Aro formed the bulk of the administrative personnel there. They wielded considerable influence on the communities (Agumagu,1988).

On the Obio axis, Okorie Mbeke was the first headman of Umu Evo Aros and Iburaikwu Apara was the head of Umuapara Aros. The Aro also played political role, as they represented their (Aro) people in the area. They used the ofo-stick (it represented the nodal point of the ancestral spirit) enforce decisions. The Obio Chiefs also used the Aro as advisers and they helped to enforce the law. At the end of judgement, fines imposed on litigants were shared among the elders and the Aro also benefited (Obio Intelligence Report Ahodist, 1932).

The Aro (Igbo) were generally feared and even respected mainly because of their oracle-Ibiniukpabi, perceived to have supernatural power. The oracle was regarded as impartial and unchallengeable. This accounts for its fame and popularity in Igboland and even beyond. The activities of the Aro oracle - made the Aro move about into the hinterland unmolested. Ofonagoro (1979) asserts that the Aro, being the custodian of this oracle, moved about to different places with immunity from local molestation. According to Akani (24/8/2009), the influence of their oracle, exerted some influence in Ikwerre local affairs. Wealthy Ikwerre people were usually singled out by the Aros through the instrumentality of their long juju, as witches and wizards and the accused persons were condemned to death and/or sold into slavery. Their possession would be confiscated under the pretence that the possession belonged to the oracle. The Aros acquired much wealth that they owned land and houses among the Ikwerre people. For instance, in Rumuokuta, Mr Nweke, an Aro and a member of the Obio customary court, acquired large portions of land in the area and built an "imposing" house. The place came to be called Ama Nweke (Nweke's villa). In Oroworukwo, they built Aro hall for their meetings and other social activities.

There were also Igbo itinerant messengers from Igwekala (Omunoha) shrine as well as native doctors from Awka, where some Ikwerre people sought protection from. They were patronized and they had links all over Ikwerre land. The Awka people combined their smith business with being the agents of their oracle. Awka people were famous

Copyright (C) International Association of African Researchers and Reviewers, 2006-2017: www.afrevjo.net.

Indexed African Journals Online: www.ajol.info 
for smelting crafts and they also had itinerant journey men who set up shops in, or near Ikwerre village markets. They fabricated such products as hoes, axes and knives, brass ankle plates and leg-coils which young girls wore during their rite of passage. Apart from the Awka people, the Nkwerre who were good blacksmiths also had early contacts with Ikwerre people. They traded in textiles and they settled in Ikwerre land.

Apart from the aforementioned, there were also immigrants from Igbo land who came to work on farms during the farming season in Ikwerreland. They enjoyed the hospitality of Ikwerre people through free accommodation. Sometimes, they were fed to reduce the amount of money paid. Some Igbo itinerant labourers were also engaged in palm fruit cutting, oil extraction for cooking and cash crops harvesting. This might explain why some Ikwerre men marry from Igboland. The masquerade pageant of Ekpo Christmas in Aluu, and some Ikwerre communities such as Omagwa, Egwu Madu is traced back to Igbo origin.

In churches and schools, the Igbo language was the lingua franca and this, to a great extent, had overwhelming effect on the culture and language of the Ikwerre, which also resulted in the original names of Ikwerre communities to being modified in Igbo language. Thus community names such as Igirita, Ogwa, Alua, Unueme, Umuigbo, Umuokoro, Umuomasi, and others are corruptions of the original Ikwerre community names: Igwuruta, Omagwa, Aluu, Rumueme, Rumuigbo, Rumuokoro, Rumuomasi, respectively (Aguma 12/12/2014).

In Elele, the Aro were settled all over. It is only on careful observation that one notices them; Unlike Igwuruta, Isiokpo, where they have clustered settlement, here they formed Aro compounds, like Aro-Omuodu, Aro-Omodukwu, Aro-Omuma, AroOgbogbu, in Igwuruta and Nmgbu Oyo in Isiokpo.

The Igbo took active part both in the local and national politics of Ikwerre. For instance, in 1964, one Mr Elegwuronu, an Igbo man, was nominated by National Council for Nigerian Congress to contest the Federal Constituency election in Port Harcourt. This was vehemently opposed by the Ikwerre people, who fielded an independent candidate in the person of Bar. W. Nwonodi, and he won the election. This was a landmark victory and a unifying factor among Ikwerre politicians (Chief Akani).

The outbreak of the Nigerian Civil War (1967-1970) led to the displacement of some Igbo (Aro) living in Ikwerre communities of Diobu-Rebisi, Aluu, Omudioga, Omagwa, Ozuoba. However, some (the Aro) are still settled in Igwuruta and Isiokpo now as their communities. In this contemporary era, the Igbo still enjoy the relationship with the Ikwerre, as they are found in the nooks and crannies of Ikwerreland carrying out their lawful businesses.

\section{Ikwerre - Hausa Relations}

Copyright () International Association of African Researchers and Reviewers, 2006-2017: www.afrevjo.net.

Indexed African Journals Online: www.ajol.info 
Ikwerre does not have any natural boundary with the Hausa, as they are thousands of miles apart. In the views of Afigbo (1981, pp. 23-24), the geography of the area (now Nigeria) does not constitute a severe impediment to intergroup relations. The movement of peoples, goods, services and ideas out of an area could take place easily and virtually imperceptibly.

A case in sight is the Hausa of Northern Nigeria and their settlement in Elele community in Ikwerre in the Niger Delta of south-south Nigeria in late 19th century. The Hausa were reported to have come on the invitation of the people of Elele in the later part of the nineteenth century to help in killing elephants that were constituting menace to their farmland. The Hausa were able to achieve this fit (eliminating the elephants) with their weapons which consisted of bows and arrows with poisoned sharp points and local Dane guns (Amadi,1984; Woke, 1993). Another hypothesis on the arrival of Hausa in Elele posits that the trade in ivory, which was buoyant at that time in European markets, could have been another reason for the Hausa arrival and eventual settlement in Elele.

On arrival, the Hausa elephant hunters/killers settled at Omuachi compound of Mbguanyim village, an area which is now called Mgbu Osukpa. The Hausa in Elele settled under the leadership of Mallam Dadi who became the first Sarki of their settlement. He was called Eze Wosukpa by the indigenes.

The arrival of the Hausa-Elele (as they are referred to) coincided with the period of colonial administration. Amadi (1984), asserts that the position of the Sarki Hausa Elele was so highly recognized by the colonial masters because of the command the Sarki had over their subjects, unlike the indigenous Elele. The British saw the HausaElele as a ready-made tool to be used in strengthening their colonial exercise having already succeeded in the north with indirect rule system.

Consequently, the Hausa occupied significant positions in Elele. They became the vehicle of communication between the British officials and the Elele. The Sarki played dominant roles in Elele politics from the nineteenth century to the 1950s so much so that the Sarki could be taken as the paramount ruler of Elele. For instance, during the reign of Mallam Muhammed Dikko as Sarki, he was recognized by the colonial government as Warrant Chief, while Hilaru Dikko was appointed the chairman of Ikwerre District Council at Choba (Amadi,1987).

With support from the colonial masters, the Sarki/Warrant Chiefs engaged in forceful acquisition of Elele land, which has continued to cause crisis between the indigenes and the Hausa-Elele. This notwithstanding, there have been intermarriages between the Hausa-Elele and Ikwerre, with the Hausa marrying more of the Ikwerre women. As is natural, the Ikwerre language has been acquired by the Hausa in Elele. Some Elele people also speak the Hausa language.

Copyright () International Association of African Researchers and Reviewers, 2006-2017: www. afrrevjo.net.

Indexed African Journals Online: www.ajol.info 
One of the most significant effects of this relationship is the introduction of the Islamic religion into Rivers/Bayelsa States through Elele. Kilani (2002) traces the beginning of the religion of Islam in the Niger Delta to Elele where the presence of Muslims was first recorded in 1896. This led to the conversion of some Ikwerre people into the practice of Islamic religion and mosques were built for the purpose.

\section{Influence of Intergroup Relations}

There is evidence of established long-standing relationship between the Ikwerre and her coastal and hinterland neighbours. They have also gained from their cultural richness.

\section{Judicial Influence}

Wobasi (1976), posited that Chief Abbii Wokaribo and other Kalabari people who lived among Emohua people joined in the adjudication of cases in the community. King Nnyevunwo of Ogbakiri tried to arbitrate in civil cases among the Kalabari and sometimes between the Bonny and Andoni. Similarly, in the precolonial time, during the Oroije and Eguma-Abali war (communities in Rebisi Diobu), Oroije took refuge with Chief George Wowhukanuga of Okrika. This created a relationship that has continued to the present. Chief Agbagbo Ohia of Oroije was an intimate friend of Chief George Wowhukanuga (Omaruta Age Group, 1989). Chief Osi of Emohua, during a war between him and the community took some of his children - Amme, Ijinda, Emeoha and Uli to Chief Omokwe of Buguma -Kalabari.

Also, in wars that ensued between Okirika and Bonny against Kalabari at different times, the Ikwerre people were caught in the middle, as they seem to have allied with the group they had better trade relations. For instance, King Amachree sought for support of the Ikwerre people of Anya (Ogbakiri) Isiodu Alibrada, Odu-Ohan (Oduoha) and Edegu, in a war with Okirika Kalabari chiefs sent arms to some Emohua Chiefs to help fight their enemies - Okrika and Okoloba. However, Aluu, Choba, Isiokpo and Agwa were in support of Bonny. Wisdom informed their decision. Economic interest determined which side to support showing.

\section{Cultural Influence}

In spite of the fact that the Ikwerre and their neigbhours do not have homogeneous cultural institutions, they have a number of things in common as a result of active crosscultural exchange due to centuries of contact. Their relations were enhanced through marriages and concubinage. Many Kalabari and Okrika men can point to Ikwerre as their maternal roots (Aguma, 12/12/2012).

These contacts were influenced by inter-linguistic assimilation, which criss-crossed between the Ikwerre and her coastal neghbours and often led to bilingualism among the people, especially traders. As such, loan words have found their way into Ikwerre

Copyright () International Association of African Researchers and Reviewers, 2006-2017: www.afrevjo.net.

Indexed African Journals Online: www.ajol.info 
language; names of objects, such as ngaji (spoon), sokiya (clock) tonji (lamp); and name of fishes like agbara, ikili, and angala were derived from Kalabari language. Egelege an Ikwerre word for wrestling, and otara-pounded yam or garri - are used by the Kalabari. This was basically due to the long contact with their riverine neigbours. Mastery of the languages gave them easy access for communication and firm association.

Wodi (14/7/2012), posited that the Elelenwo- Ikwerre mastered the Okrika language to the extent that during marriage negotiation for wife in Okrika, the Elelenwo spoke Okrika, and when the Okrika came to Elelenwo- Ikwerre for the same purpose, they used the Ikwerre language for the negotiation.

It is significant to note that the relations further strengthened their friendship, which led to such coastal based names like Amakiri, Iyalla, Wariboko, and Wokoma, borne by some Ikwerre people. On the other hand, names like Wenike and Dimkpa are Ikwerre names borne by the Kalabari people.

Coral beads which were highly priced in the Niger Delta region were brought from the coastal traders by some wealthy families in Ikwerre. The Ikwerre chiefs use this to adorn their daughter especially during the Ojiji/Mgbede festivals. Coral beads are a sign of aristocracy or at least of middle class. Chiefs use them to adorn their robes, women also use them for necklaces and bangle.

Another feature of the intergroup relation was cultural dances and masquerade display. For instance, Emohua, Ogbakiri, Akpor, Isiokpo, Elelenwo, Diobu took active interest in coastal masquerade dances, like Ekpefalabo, Okii, Ofrima, Owuama, among others. Dance, music and displays from hinterland cultures penetrated into Kalabari culture and were adopted by their artistes. The masquerade and dances, like Ogburumadukwe and eregbu of the Ikwerre, were popular plays and dances in Kalabari communities (Emejuru, 18/8/2012).

Wrestling (Egelege) is another form of relationship that exists between the Ikwerre and their coastal neighbours. The Choba, Rebisi (Diobu), Elelenwo, Woji have inter-group wrestling festival with the Kalabari and Okrika people. They travel to either side of the communities for wrestling, depending on how it is agreed upon.

Some Ikwerre people consulted the deities of their hinterland neighbours such as Ibinupkabi of Arochukwu, Igwe ka ala of Umunoha, Amadi ohna of Etche and other deities of their coastal neighbours where they sought justice and protection in times of challenge. This further perpetuated the web in their relationships.

Also, the Ikwerre received the Christian faith and subsequently education through the conversion experiences of their Kalabari and Okrika neighbours. Initially, the Ikwerre people attended church services and schools in these communities before they were established in Ikwerreland. During the era of colonial administration, Ikwerre formed

Copyright (C) International Association of African Researchers and Reviewers, 2006-2017:

www.afrevjo.net.

Indexed African Journals Online: www.ajol.info 
part of the old Degema Division and all the native courts in Ikwerre were under the direct supervision and control of the District Commissioner at Degema. This made the Ikwerre to attend their court cases at Degema, until 1928, when for nearness and administrative convenience, Ikwerre was excised from Degema Division and made part of Ahoada Division. Presently, there are three courts in Ikwerreland.

\section{Conclusion}

It is evident that a great deal of interaction existed between the Ikwerre and her neighbours. They have enjoyed longstanding relationships with their coastal neigbhours as well as their hinterland in terms of historical origin, conflicts, migrations, trade, marriage and other aspects of their culture. The strategic position of the Ikwerre people, more importantly, the natural vegetation was a factor in determining the relations between the Ikwerre and their neighbours. This relationship was predicated on trade. This meant the Ikwerre did not evolve in isolation from their neighbours. Thus, the internal developments which were stimulated by their contacts impacted significantly on the culture of the Ikwerre and their neighbours. To a very great extent, the cultural exchanges and marriages served as conduits for acculturation for the Ikwerre and their coastal and hinterland neigbhours. The importance of the inter-group relations is relevant especially as it will serve as guide in this season when most communities in Rivers State and beyond are engulfed in one crisis or the other.

\section{References}

Afigbo, A. E. (1980). Igboland before 1800. In Ikime, O. (ed.), Groundwork of Nigerian history. Ibadan: Heinemann Educational Books Nigeria Ltd.

Afigbo, A. E. (1981). The age of innocence: The Igbo and their neigbhours in precolonial times. Ahaijoku Lecture. Ministry of Information and Culture, Youth and Sports, Government Printer, Owerri.

Alagoa, E. J. \& Fombo, A. (eds.) (2001). Chronicle of grand Bonny. Ibadan: Ibadan University Press.

Alagoa, E. J. \& Kiebel, C. B. (1989). Traditions of origin. In Alagoa E. J.\& Tamuno, T. N. (eds.). Land and peoples of Nigeria: Rivers State: Port Harcourt: Riverside Communications.

Alagoa, E. J. (1972). A history of the Niger Delta: An historical interpretation of Ijo oral tradition. Ibadan: University of Ibadan Press.

Alagoa, E. J. (1976). The Niger Delta States and their Neighbours, to 1800. In Ade Ajayi, J. F. \& Crowder, M. (eds.). History of West Africa Vol. I. UK: Longman Group Ltd.

Copyright (C) International Association of African Researchers and Reviewers, 2006-2017: www.afrevjo.net.

Indexed African Journals Online: www.ajol.info 
AFRREV VOL. 11 (2), S/NO 46, APRIL, 2017

Alagoa, E. J. (1980). The Eastern Niger Delta and the Hinterland in the 19th Century. In Ikime, O (ed.), Groundwork of Nigerian history. Ibadan: Heinemann Education Book.

Amadi, E.W. (1984). Hausa-Elele: Its development and impact on Elele wider community 1890 to present. B.A. Project, Dept of History. University of Port Harcourt.

Amadi, K. O. (2003). The Ikwerre people and their neighbours. Nduka, O. (ed.). Studies in Ikwerre history and culture Vol. II. PortHarcourt: University of Port Harcourt Press.

Dike, K. O. (1956). Trade and politics in the Niger Delta,1830-1883. Oxford: Claredon University Press.

Eke, S. C. \& Chuku, D. C. (2003). Onomastics in Ikwerre. PortHarcourt: Osai Int'1 Publishers Ltd.

Intelligence Report on Emohua Clan - Ahoada Division Owerri Province OW1750 Ahodist 10/1/22.

Intelligence Report on the Rumiji Native Court Area Ahodist 14/1/22 file No. 102.

Intelligence Report or Ikwerre Clan - Ahoada Division Ahodist 12/1/2

Kilani, A. R. O. (1998). Origin, growth and impact of Islam in Port Harcourt and its environs, 1896-1997. Ph.D. Thesis, University of Port Harcourt.

Nwala, U. E., Orji, K. \& Sokori-George, G. (2009). The Izon and their Igboid neighbours. In Alagoa, E. J, Tamino, T. N. \& Clark, J. P. (ed) (2009). The Izon of the Niger Delta. Port Harcourt: Onyoma Research Publication

Nwanodi, N. (1994). The Port Harcourt question. A manifestation of political power. Port Harcourt: Royal Associates.

Ofonagoro, W. I. (1979). Trade and imperialism in Southern Nigeria: 1881-1929. New York: Nok Publishers International.

Otite, O. (n.d.) On the concept of a Nigeria society. In Sanda, A. O. (ed.) Ethnic relations in Nigeria: Problems and prospects. Ibadan: The Caxton press (West Africa) Ltd p.3.

Okpara, A. P. (1979). King Nnyevunwo of Ogbakiri. In Tamuno, T. N. \& Alagoa, E. J. (eds.). Eminent Nigerians of the Rivers State. Ibadan: Heinemann.

Okpeh, O. O. (2006). Conceptual and theoretical issues arising from students in intergroup relations in Nigeria in the 20th century. In Akinuunmi, O., Okpeh O. O.,

Copyright (C) International Association of African Researchers and Reviewers, 2006-2017:

www.afrrevjo.net.

Indexed African Journals Online: www.ajol.info 
Jr., Gwamna, J. D. (eds.). Inter-group relations in Nigeria during the 19th \& 20th Centuries. Makurdi - Ibadan - Abuja: Aboki Publishers.

Olise, J. N. (1977). Otuwarikpo, E. E (1994), Solomon, N.M.T (2004). As recorded in the 10th Ikwerre Yearly Thanksgiving Day. Theme: For the Love of Ikwerre and Rivers State in Christ, 26th Dcember, 2009, Port Harcourt.

Omaruta Rebisi Age Group, (1989). Rebisi: A historical account. Port Harcourt: Sacrum Graphic Press.

Report on the History and Organization of the Ikwerre People living in Elele and Nkarahie Court Areas - Ahoada Division Ahodist 14/1/217 file No. 96.

Wahua, T. A. T. (1993). Farming System in Ikwerre. In Nduka, O. (ed.), Studies in Ikwerre history and culture Vol..1. Ibadan: Kraft Books Ltd.

Wariboko, W. E. (1989). Social and political development. In Alagoa, E. J. \& Tamuno, T. N. (eds.) Land and People of Nigeria: Rivers State Port Harcourt: Riverside Communications, pp:125 -129.

Wobasi, O. O. (1976). Report on Ikwerreland phase I It's geographical, social and political organization, and pre-colonial external relations. University of Ibadan: Junior Research Fellow, Institute of African Studies.

Woka, S. (1993). The origin of Ikwerre. Akwa: An Ikwerre Socio-cultural Journal, Ogbakor Omenele, Vol. I. Elele: Omenelele 